\title{
RISK MANAGEMENT OF FLOODING IN THE ROMANIAN SECTOR OF THE DANUBE
}

\author{
Lavinia Georgiana PASCU ${ }^{1}$ \\ Alecu TOMA ${ }^{2}$ \\ lonut Georgian ZAMAN ${ }^{3}$
}

${ }^{1}$ Eng., Navy Application School, Mangalia, România, laviniageorgiana.pascu@yahoo.com

${ }^{2}$ Eng.,PhD, „Mircea cel Batran” Naval Academy, Constanța, Romania, alecu.toma@anmb.ro

${ }^{3}$ Eng., Navy Application School, Mangalia, Romania, Ionut georgian92@yahoo.ro

\begin{abstract}
Flooding is threatening many millions of people in Europe. It is the most widely distributed of all natural hazards across Europe with floods from rivers, estuaries, and the sea. Floods, wherever they happen, cause distress and damage. The data from insurance company shows that the financial impact of flooding has increased significantly since 1990. The present paper aims to study the high - risk flood areas on the Romanian Danube.
\end{abstract}

Keywords: The Danube, flood, risk management.

\section{Flood risk}

Floods have the potential to cause loss of life, evacuations of people and damage tothe environment, to severely compromise economic development and undermine the economic activities of the communities. It is feasible and desirable to reduce the risk of adverse consequences especially for human health and life, for the environment, cultural heritage, economic activity and infrastructure associated with floods. However, the measures to reduce these risks, to be effective, should, where possible, be coordinated throughout a river basin. The biggest problem in flood risk management is the risk accepted by the population and decision makers, knowing that there is not a complete protection against flooding (zero risks), as there is no consensus on acceptable risk. Flood risk is characterized by the nature of it (floods from rivers, fast high floods, floods caused by increasing groundwater levels, flooding caused by marine storms, exceptional floods caused by accidents / incidents at hydraulic structures dams, dykes) and their associated probability of occurrence, correlated with the exposure of the receptor, resulting that on risk reduction must be acted upon its features. Reducing the consequences of flooding is the result of extensive combinations of measures and actions preceding the occurrence of the incident (activities of prevention, protection and preparation), the management during floods (response actions taken during floods, known as emergency management) and those undertaken after the

DOI: 10.21279/1454-864X-16-12-010

(c) 2015. This work is licensed under the Creative Commons Attribution-Noncommercial-Share Alike 4.0 License. flood (reconstruction and lessons due to the occurrence of the phenomenon).

Directive 2007/60/EC on the assessment and management of flood risks aims reducing negative consequences for human health, environment, cultural heritage and economic activity associated with floods. In this regard, the member states have the obligation to identify river basins and coastal areas at risk of flooding, to draw up flood risk maps and to develop flood risk management plans for these areas. The primary information on flood risk areas has been made by Water Basin Administrations, through the Offices of Defense against floods under the technical coordination of INHGA (National Institute of Hydrology and Water Management) who prioritized, selected and validated the information provided in the entire territory.

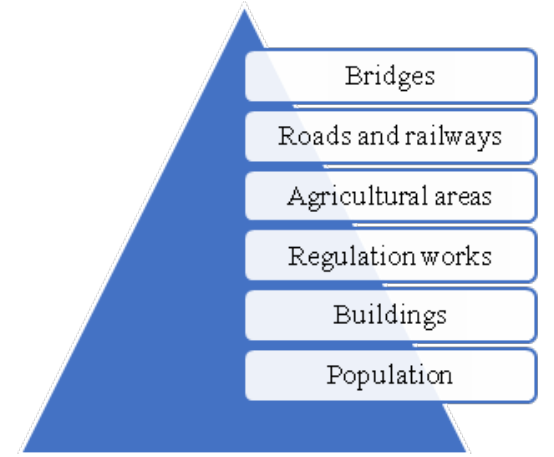

Figure 1 The prioritization of damages

Preliminary assessment of flood risks (EPRI) involves identifying significant historical floods and significant flood risk areas (Report - "Assessment 
"Mircea cel Batran" Naval Academy Scientific Bulletin, Volume XIX - 2016 - Issue 2

The journal is indexed in: PROQUEST / DOAJ / Crossref / EBSCOhost / INDEX COPERNICUS / DRJI / OAJI I

JOURNAL INDEX I I2OR / SCIENCE LIBRARY INDEX / Google Scholar I Academic Keys/ ROAD Open Access I

Academic Resources / Scientific Indexing Services / SCIPIO / JIFACTOR

of primary flood risk. Danube basin"www.rowater.ro). In determining significant flood risk areas was firstly considered, the currently available information:

$>$ potential flood areas through highlighting historical extreme floods;

$>$ evaluation of the potential impact of flooding (potential consequences).

The prioritization of the assessment of damages is shown in figure 1.

In this case, they were taken into account all the floods that occurred in the past and which had significant adverse impacts on human health, environment, cultural heritage and economic activity, without removing from the list those floods that may occur in sectors that had been built hydro dams. Equally, it was considered the technological risk of embankment works on those areas which, although are protected for certain categories of events, they could be flooded in case of:

$>$ potential dam or levee breaks;

$>$ extreme events, which would be greater than the protection established by computing project.

\section{Historical significant floods}

The selection of significant historical flooding was achieved by applying the criteria for each country, the directive providing freedom for each member state to define the term significant historic flood.

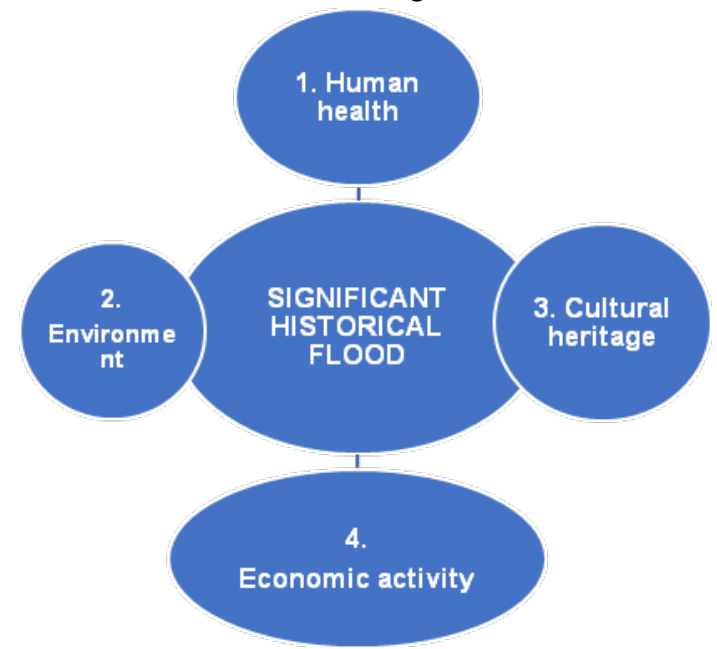

Figure 2 The criteria which led to the identification of historic floods in Romania

The criteria that led to the identification of historical floods in Romania was the hydrological one and the criteria for the negative effects of flooding on the four categories of consequences set out in the Directive, according to figure 2.

Information needed to identify historic floods in Romania is:

$>$ Geographic information - maps of areas affected by historical significant floods;

$>$ Date - Specific information from Basin Administrations regarding the identified significant historical floods on the territory in the form of reports;

$>$ Text information (Summary) - analysis to identify significant historical floods was based on the methodology developed by experts of MMP (Ministry of Environment and Forests), NAAR (National Administration of „Romanian Waters") and INHGA.

The affected areas in Romania are shown in figure 3 and 4 .

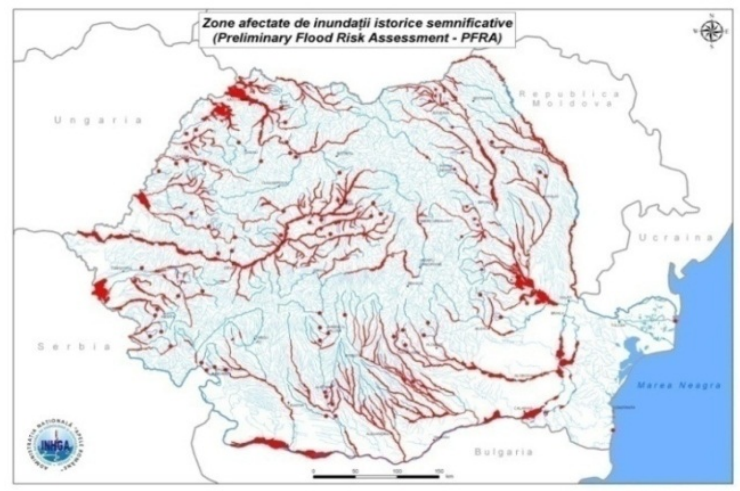

Figure 3 National map of affected areas

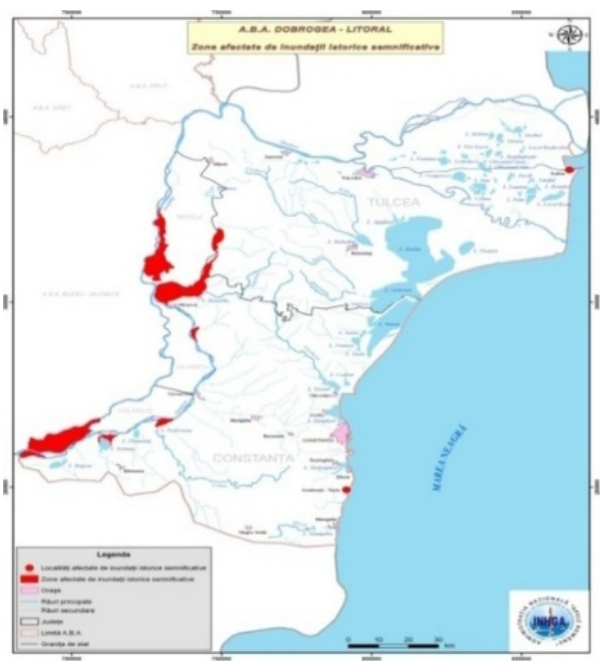

Figure 4 The map of areas affected by floods historical significant floods in Dobrogearegion 3. Significant flood risk areas identified in the Danube basin 
"Mircea cel Batran" Naval Academy Scientific Bulletin, Volume XIX - 2016 - Issue 2 The journal is indexed in: PROQUEST / DOAJ / Crossref / EBSCOhost / INDEX COPERNICUS / DRJI / OAJI I JOURNAL INDEX I I2OR / SCIENCE LIBRARY INDEX / Google Scholar I Academic Keys/ ROAD Open Access I Academic Resources / Scientific Indexing Services / SCIPIO / JIFACTOR

Along the Danube are 23 hydro stations that measure the river level as shown in Figure 5. Data concerning rates achieved by the river are provided by the "River Administration of Lower Danube" Galati (AFDJ). Diagnosis and hydrological forecasts for the Danube from entering the country and the Romanian sector are provided by INHGA.In figure 6 are shown the significant flood risk areas identified on the Danube.

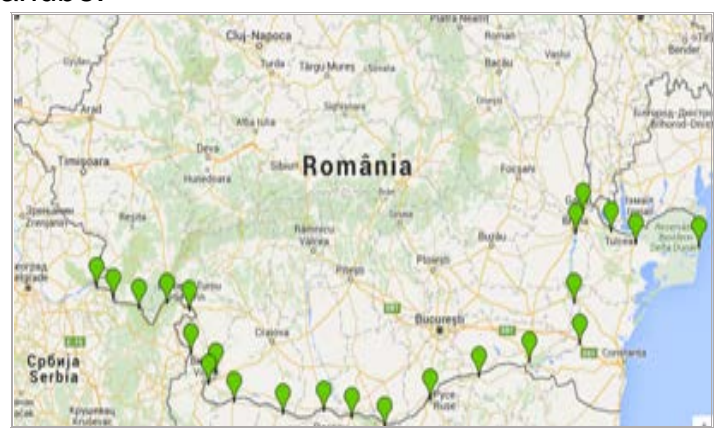

Figure 5 The position of hydrometric stations on the Danube

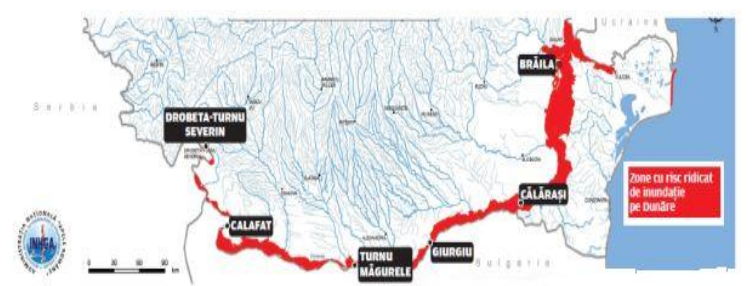

Figure 6 Locating significant flood risk areas identified on the Danube

The data provided by the Water Basin Administrations, through the Offices of Defense against floods and technical coordination of the National Institute of Hydrology and Water Management, demonstrates thatBig Island of Braila is one of the most affected areas in case of flooding. This information was also confirmed, in 2006, when floods hit this area (figure 7).

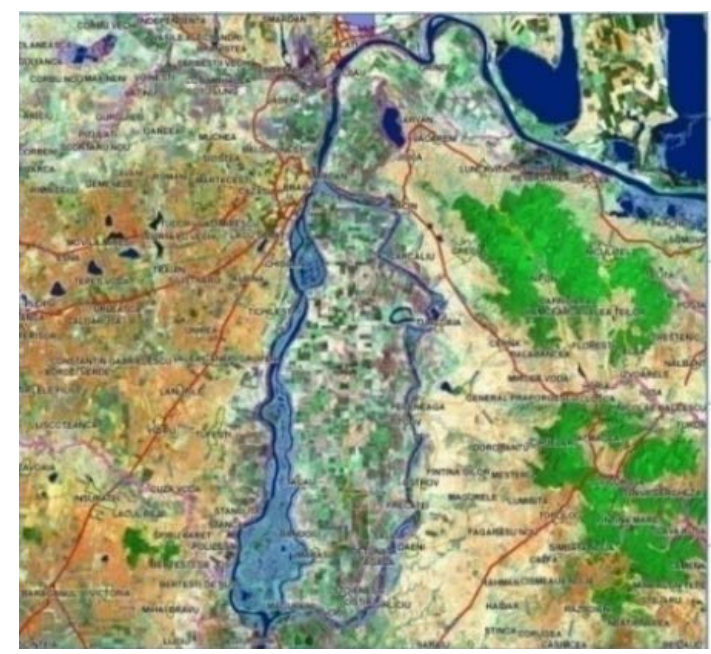

Figure 7 Danube Valley flooded areas: Sector

Big Island of Braila, 31.03.2006, 10:45

In the process of implementing Directive 2007/60 / $\mathrm{EC}$ on the assessment and management of flood risk, were drawn flood risk maps for areas designated as having significant potential flood risk in the first stages of implementing Directive 2007/60 / EC. In accordance with the requirements of the Directive, flood risk maps show the potential adverse consequences associated with the following terms outlined in figure 8.

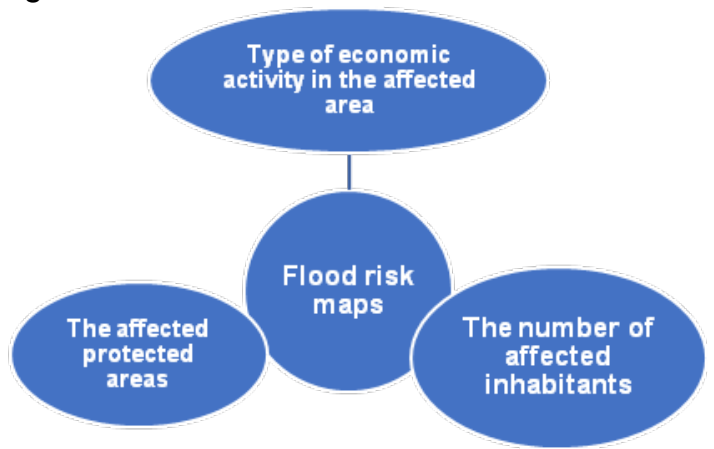

Figure 8 Thenegative potential effects associated with flood risk maps

Flood risk mapsfor the Big Island of Braila are shown in figure 9. 
"Mircea cel Batran" Naval Academy Scientific Bulletin, Volume XIX - 2016 - Issue 2

The journal is indexed in: PROQUEST / DOAJ / Crossref / EBSCOhost / INDEX COPERNICUS / DRJI / OAJI I JOURNAL INDEX I I2OR / SCIENCE LIBRARY INDEX / Google Scholar / Academic Keys/ ROAD Open Access I Academic Resources / Scientific Indexing Services / SCIPIO / JIFACTOR

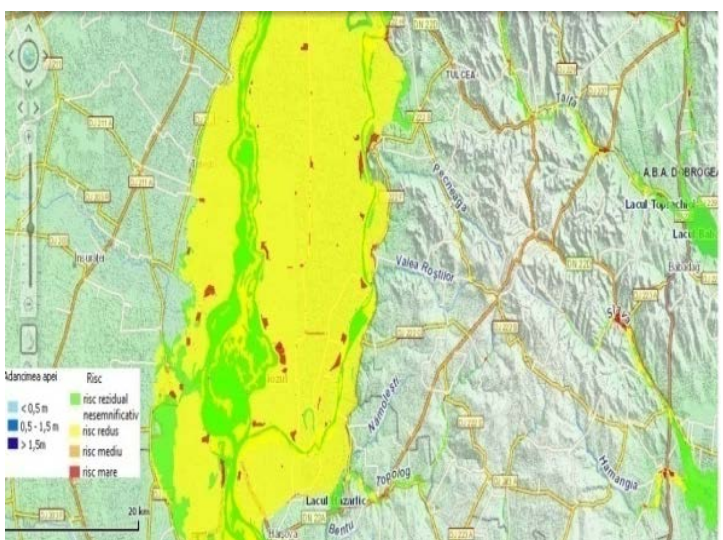

Figure 9 Flood risk maps. Big Island of Brăila area

\section{Big Island of Braila}

The Big Island of Braila defends against flood an area of over 72,000 ha between Macin river and Valciu river, which includes Marasu and Frecatei villages and also schools, community centers, medical and veterinary facilities and trade points, „Blasova” recreation area (School Camp with 200 places to stay and other holiday houses), $100 \mathrm{~km}$ electric airlines and two piscicultural spaces (Blasova and Zaton). Flood protection system consists of a dam built in 1964 on the entire area of Big Island of Brăila, with a length of about 175 $\mathrm{km}$ (86 km on Macin river, $64 \mathrm{~km}$ on Valciu river and $25 \mathrm{~km}$ of subdivision works), a grid of drainage channels with a length of $136 \mathrm{~km}$ (build during 1967-1972) and 30 electric pumping stations. In the vicinity of the dam are 11 cantons, continuous surveillance points, for primary notification, storage of materials for intervention and coordination of small proportions activities.In table 1 and figure 10 can be seen the historicallevels of Danube in the area of Braila.

Table 1 Danube levels in Braila

\begin{tabular}{|c|c|}
\hline Date & Level \\
\hline June 2003 & $37 \mathrm{~cm}$ \\
\hline March 2006 & $608 \mathrm{~cm}$ \\
\hline June 2010 & $696 \mathrm{~cm}$ \\
\hline July 2010 & $713 \mathrm{~cm}$ \\
\hline January 2011 & $550 \mathrm{~cm}$ \\
\hline November 2011 & $22 \mathrm{~cm}$ \\
\hline December 2011 & $41 \mathrm{~cm}$ \\
\hline January 2012 & $116 \mathrm{~cm}$ \\
\hline June2014 & $638 \mathrm{~cm}$ \\
\hline
\end{tabular}

Danube's maximum levels had been registered in the years: 1897, 1940, 1942, 1954, 1970, 1975, 2006 and 2010, when in Braila was

DOI: 10.21279/1454-864X-16-12-010

(c) 2015. This work is licensed under the Creative Commons Attribution-Noncommercial-Share Alike 4.0 License. reached the maximum level of $713 \mathrm{~cm}$. There is a periodical increase level. The largest increases are occurring during March-April and June-July.

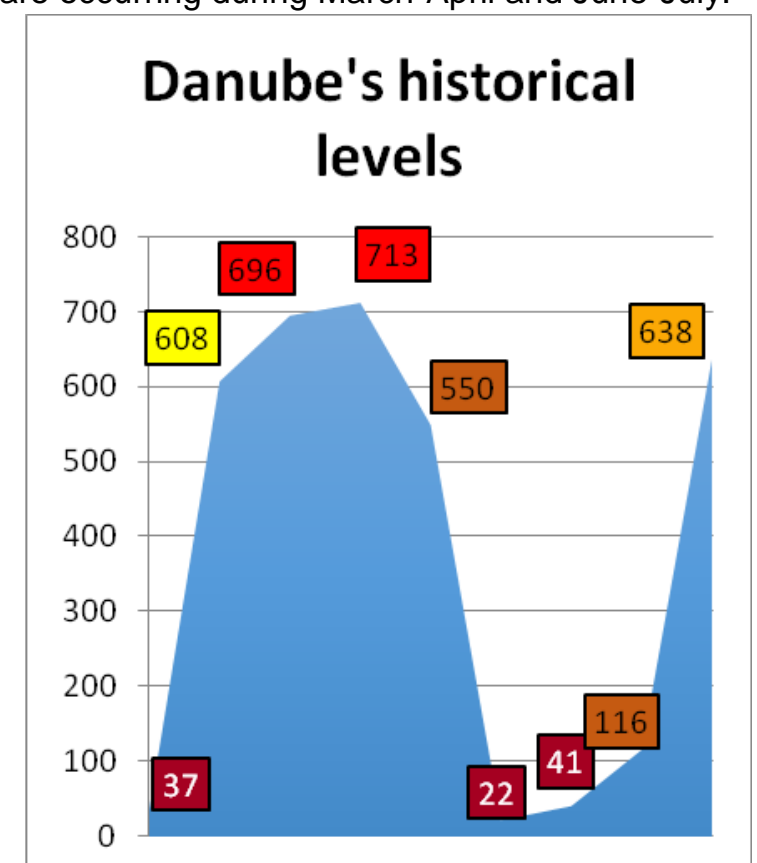

Figure 10 Chart - Historical levels of Danube

Floods may affect the administrative territory due to the fact that the Danube passes near Frecatei village; in the eastern part, the most exposed to the risk are the following villages: Titcov, Frecatei, Salcia, Agaua and Cistia. Due to the level and the increased flow of the river, infiltrations occur, and the embankment of defense dams can break down because of the humidity.

The water resulting from the infiltrators is taken by the drainage channels using pumping stations and water is pumped into the Danube through water drainage stations.

\section{Characteristic defense values in case of floods}

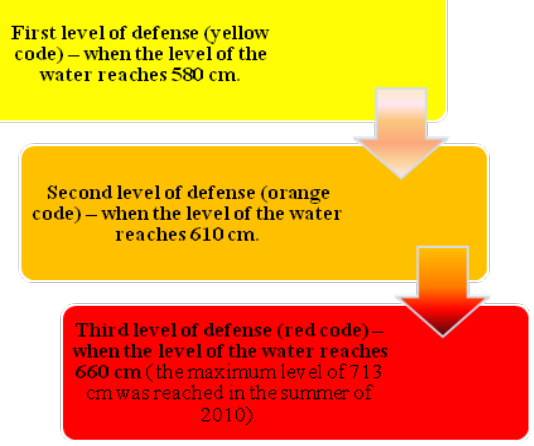

Figure 11 The levels of defense in case of floods 


\section{"Mircea cel Batran" Naval Academy Scientific Bulletin, Volume XIX - 2016 - Issue 2 The journal is indexed in: PROQUEST / DOAJ / Crossref / EBSCOhost / INDEX COPERNICUS / DRJI / OAJI I JOURNAL INDEX I I2OR / SCIENCE LIBRARY INDEX / Google Scholar / Academic Keys/ ROAD Open Access I Academic Resources / Scientific Indexing Services / SCIPIO / JIFACTOR}

For the dammed areas of the Danube in Braila area, the critical limits of defense are shown in figure 11.

\section{Disaster scenarios}

The anticipated disaster scenarios are represented in figure

\section{Disaster scenarios}

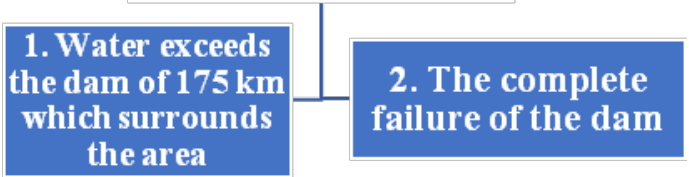

Figure 12 Disaster scenarios

The most severe scenario represents the maximum level of severity when Big Island of Braila would be overflowed in about 36-48 hours. The construction of the $175 \mathrm{~km}$ long dam which surrounds the area was started in 1964 and completed in 1968. Today, the agricultural land occupies $94.6 \%$ of the island, for about $681.3 \mathrm{~km}^{2}$. There are ten small villages where about 5000 6000 people live. If the dam would break down because of the floods on the Danube, or the waters are higher than the level of the dam, the water can reach a depth of 1.5 - 5 meters.

When the National Institute of Hydrology and Water Management will announce the yellow code warning and announces the increase of the level and also the danger of floods in the immediate period, it will be established a state of emergency and the authorities will take the necessary measures to limit the water level for saving the people.

\section{Activities that will take place at floods}

Evacuation - is a protective measure taken in case of an imminent threat, alertness or occurrence of an emergency and consists of removing from the affected or potentially affected areas, in an organized manner, the public institutions, businesses, categories or groups of people or goods. They will be displaced in villages which provide protection of persons, goods, businesses and public institutions. The purpose of actions for evacuation in case of floods is the occurrence of hydrological phenomena that can cause flooding, ensuring the protection of people and goods from affected areas.

\section{CONCLUSIONS}

Floods have the potential to cause loss of life and damage to the environment, to severely compromise economic development and undermine the economic activities of the communities. Directive 2000/60/EC on the assessment and management of flood risks establishes a framework for political community action in the field of water and requires to organize river basin management plans for each river basin to achieve good ecological and chemical status, contributing to the reduction of the floods effects. The essential issue in flood risk management is that there is not a complete protection against floods (zero risk). The Directive 2007/60/EC on the assessment and management of flood risks aims to reduce the negative consequences for human health, environment, cultural heritage and economic activity associated with floods. INHGA provides diagnosis and hydrological forecasts for the Danube from entering the country and the Romanian sector. It was concluded that all areas crossed by the Danube River are vulnerable to flooding and the Big Island of Braila is one of the most affected areas in this case, as was demonstrated in 2006 when floods considerably affected this area.

\section{BIBLIOGRAPHY}

[1] http://afdj.ro

[2] http://www.danube-ports.ro

[3] http://www.infodanube.ro

[4] http://www.inha.ro

[5] http://www.rowater.ro

[6] „PlanulUrbanistic General Braila”, http://www.primariabraila.ro. 